\title{
THE MEASURE OF RECOVERY UPON IMPLIED AND QUASI-CONTRACTS
}

The term, "implied contract," is an ambiguous one; for it may mean a real agreement of parties, which, however, is not expressed in words, but is understood by both parties from the circumstances, or it may mean a claim, equitable in its nature, to get back something which, if the holder were to keep it, would result in unjustly enriching him. The amount of recovery upon an implied contract, so called, may therefore be governed by the ordinary rules applied to an express contract, or it may be determined according to the justice or injustice of the defendant's claim to retain a benefit. A somewhat careful analysis of the cases is therefore necessary in order to arrive at a satisfactory settlement of the measure of damages. For this pirpose, the cases may be divided into four classes:

I. Where there is an express contract substantially performed.

2. Where there is an express contract unperformed.

3. Where an express contract has been rescincled.

4. Where there never was an express contract.

I.

\section{Express Contract Sunstantially Performed.}

Where a contractor, performing his contract in good faith, substantially complies with his obligation, but makes some comparatively slight deviations, he may recover compensation for the work done. ${ }^{1}$ While there is general agreement on this point. among the authorities, the rule for determining the amount of recovery is very differently stated by the different courts. The rule most commonly laid down is that the contractor may recover

${ }^{1} \mathrm{He}$ cannot, strictly speaking, recover on the special contract, and therefore if the original obligation was in the form of a covenant, an action of covenant will not lie on substantial performance. Clayton $v$. Blake, 4 Ired. (N. C.), 497. 
the contract price, less an allowance for the damage caused by the cleviation. ${ }^{2}$

This rule is often stated more specifically in this form-that where performance substantially conforms to the contract, but varies in some particulars from the specifications, the amount to be deducted from the contract price is the reasonable cost of remedying such defects as are remediable without unreasonable expenditure, ${ }^{3}$ and so far as the defects cannot be remedied, the diminished value of the performance, compared with complete performance. ${ }^{4}$ It is often held, however, that the measure of

2 The Lucille Manor, 70 Fed. 233; Springfield Milling Co. v. Barnard \&. Leas Manuf. Co., 81 Fed. Rep., 26r, 26 C. C. A., 389; Barkalow v. Pfeiffer, 38 Ind., 214; Aetna Iron \& Steel Works v. Kossuth County, 79 Ia., 40, 44 N. W. 2I5; Bassett v. Sanborn, 9 Cush. (Mass.), 58; Gleason v. Sinith, 9 Cush., 484, 57 Am. Dec. 62; Kenworthy v. Stevens, I32 Mass., I23; Norwood v. Lathrop, I78 Mass., 208, 59 N. E. Rep., 650; Leeds v. Little, 42 Minn., 4I4, 44 N. W., 309; Yeats v. Ballentine, 56 Mo., 530; Decker v. School Dist., 74 S. W. 390 ; Bozarth v. Dudley, 44 N. J. L., 304, 43 Am. Rep. 373; Feeney v. Bardsley, 66 N. J. L., 239, 49 Atl. Rep., 443; Phillip v. Gallant, 62 N. Y., 256; Woodward v. Fuller, 80 N. Y., 312; Nolan v. Whitney, 88 N. Y., 648; Smith v. Gugerty, 4 Barb., 6i 4 ; Sinclair v. Tallmage, 35 Barb., 602; Goldsmith v. Hand, 26 Ohio St., Ior; Johnson v. Slaymaker, 18 Ohio Ct. Ct., I04; Chambers v. Jaynes, $4 \mathrm{~Pa}$., 39; Danville Bridge Co. v. Pomroy, I5 Pa., 151; Truesdale v. Watts, 12 Pa., 73; Wade v. Haycock, $25 \mathrm{~Pa}$., 382; Moore v. Carter, $146 \mathrm{~Pa} .492,23$ Atl. Rep., 243; White v. Braddock Borough School Dist., I59 Pa., 201, 28 Atl. Rep., I36; Shires v. O'Connor, 4 Pa. Super. Ct. 465; Aldrich v. Wilmarth, 3 S. D., 523, 54 N. W. Rep., 81I ; Bishop v. Price, 24 Wist, 480 . It is generally held that the burden of bringing in evidence of the damage caused by the deviation is on the defendant. Fitts $v$. Reinhart, Io2 Iowa, 3II, 7I N. W. Rep. 227; Leeds v. Little, 42 Minn., 414, 44 N. W. Rep. 309; Filbert v. Phila., I8I Pa., 530, 37 Atl. 545. In Massachusetts, however, the burden appears to be on the plaintiff. Gillis v. Cobe, I77 Mass., 584,59 N. E. Rep. 455 . In a few cases full recovery of the contract price upon substantial performance appears to have been allowed, but the cout was probably not dealing with the question of reduction. Linch $v$. Paris Lumber \& Grain Elezator Co., 80 Tex., 23 ;, I5 S. W. Rep. 208.

${ }^{3}$ Cutler v. Close, 5 C. \& P., 337; Pinches v. Swedish Lutheran Church, 55 Conn., 183, ro Atl. 264; Keeler v. Herr, I57 Ill., 57, 4I N. E., 750; Walker v. Orange, I6 Gray, 193; Sheldon v. Leahy, III Mich., 29, 69 N. W. Rep. 76; Leeds v. Little, 42 Minn., 4I4, 44 N. W., 309; Haysler $v$. Owen, 6r Mo., 27o; Crouch v. Gutmann, I34 N. Y., 45, 3I N. E. Rep., 27I; Pallman v. Smith, I35 Pa., 188; Shires v. O'Connor, 4 Pa. Super. Ct. 465; Ashland, L. S. \& C. Co. v. Shores, 105 Wis., I22, 8I N. W. 136.

4 Cullen v. Sears, II2 Mass., 299; Eaton v. Gladwell, I2I Mich., 444, 449. 80 N. W. Rep., 2II ; Morton v. Harrison, 52 N. Y. Super. Ct. 305; Ashland, L. S. \& C. Co. v. Shores, ro5 Wis., I22, 8I N. W., I36. 
recovery is the value of the performance, ${ }^{\circ}$ or the amount of benefit conferred on the defendant; though in every case where the point is raised it is of course held that this recovery cannot exceed the contract price, ${ }^{7}$ to the benefit of which the defendant has a right, ${ }^{8}$ deducting therefrom the damages for non-performance. ${ }^{9}$

The true doctrine appears to be that recovery can in no case exceed the contract price, less proper allowance for the defective performance; nor on the other hand can it exceed the benefit conferred. ${ }^{10}$ Since the plaintiff has not exactly performed his contract, he cannot justly claim the benefit of any profit that would have come to him by performing it; and on the other hand the defendant is entitled to be left in no worse position than he would have occupied had the contract been performed, and therefore should be held to pay no more than the contract price, less the allowance for non-performance.

Without considering whether the work done on the contract amounts to substantial completion of it, the contracting party may nevertheless recover, without establishing substantial performance, by showing an acceptance of his work by the other party. In that case the contractor is entitled to compensation as

5 Woodruff v. Hough, 9x U. S., 596; Pinclies v. Swedish Lutheran Church, 55 Conn., 183, 1o Atl. 264; Morford v. Ambrose, 3 J. J. Marsh., 688; Norris v. School Dist., I2 Me., 293, 28 Am. Dec., I82; Veasie थ. Bangor, 5I Me., 509; Smith v. First Cong. Meeting House, 8 Pick, 178; Lord v. Whecler, I Gray, 282; Atkins v. Barnstable, 97 Mass., 428; Powell v. Howard, I09 Mass. 192; Allen v. McKibbin, 5 Mich., 449 ; Wildey v. School Dist., 25 Mich., 419; Phelps v. Beebe, 71 Mich., 554, 39 N. W., 76r; Williams v. Porter, 5I Mo., 44I; Freeman v. Aylor, 62 Mo. App., 613; Decker v. School Dist., 74 S. W., 380; Nezman v. McGregor, 5 Ohio, 349, 24 Am. Dec., 293.

- Bertrand v. Byrd, 5 Ark., 65I ; Walsh v. Jenvey, 85 Md., 240; 36 Atl., 817; Bassett v. Sanborn, 9 Cush. 58; Cardwell v. Bridge, 9 Allen, 355; Norwood v. Lathrop, 178 Mass., 208, 59 N. E. Rep., 650.

7 Pinches v. Swedish Lutheran Church, 55 Conn., 183, Io Atl., 264; Morford v. Ambrose, 3 J. J: Marsh, 688; Walsh v. Jenvey, 85 Md., 240, 36 Atl. Rep. 817; Atkins v. Barnstable, 97 Mass., 192.

${ }^{8}$ Aetna L. \& I. Works v. Kossuth County, 79 Ia., 40, 44 N. W., 215.

- Escott v. White, 10 Bush (Ky.) 169; Allen v. McKibbin, 5 Mich., 449; Wildey v. School Dist., 25 Mich., 4I9; Phelps v. Beebe, 7I Mich., 554, 39 N. W. Rep., 76r ; Freeman v. Aylor, 62 Mo. App., 6rз; Decker v. School Dist., 74 S. W. Rep., 390.

${ }_{10}$ Gillis v. Cobe, 177 Mass., 584, 59 N. E. Rep., 455; Yeats v. Ballentine, $56 \mathrm{Mo}$., 530 . 
he would be if he proved substantial performance. If the acceptance was involuntary or caused only by the necessity of the case, as for instance, where it consisted of building a house or other structure upon land, the owner, by using the fruits of the work, does not accept it, since he cannot make use of his own land without enjoying the fruits of the work; and his doing so is no waiver of the right to claim that the contract was not performed. ${ }^{11}$

The courts are, however, acute to find acceptance even in such cases and any act of approval is sufficient for the purpose. The measure of damages in this class of cases is the value of the work, ${ }^{12}$ not exceeding the contract price, ${ }^{13}$ with the right in the defendant to recoup damages for non-performance. ${ }^{14}$ But the contractor is under no circumstances entitled to a profit which he would have realized if he had complied with his engagement. ${ }^{16}$

II.

EXPRESS CONTRACT UNPERFORMED.

Where the contract is on its face an entire one, and has been performed only in part, a substantial portion of the contract being left unperformed, or where after substantial performance the contractor wilfully and without excuse abandons further performance, the contractor, thus having deliberately failed to carry

${ }^{11}$ Munro v. Butt, 8 El. and Bl., 738; English v. Wilson, 34 Ala., 20I; Bertrand v. Byrd, 5 Ark., 65I; Zottman v. San Francisco, 20 Cal, 96; J. M. Griffith Co. v. Los Angeles, 54 Pac., 383; Morford v. Mastiu, 6 T. B. Mon., 609, 17 Am. Dec., I88; Yeats v. Ballentine, 56 Mo., 530; Bozarth v. Dudley, 44 N. J. L., 304, 43 Am. Rep., 373; Eldridge v. Rowe, 7 Ill., 9I ; Lowe v. Sinklear, 27 Mo., 308.

${ }_{12}$ Merriweather v. Taylor, I5 Ala., 735; Hawkins v. Gilbert, I9 Ala., 54; Bell v. Teague, 85 Ala., 2Ir, 3 So. Rep., 86r; Simpson v. McDonald, 2 Ark., 370; McClure v. Secrist, 5 Ind., 3I; Williams v. Porter, $5 \mathrm{I}$ Mo., 44I; B. \& O. R. Co. v. Lafferty, 2 W. Va., I04; Taylor v. Williams, 6 Wis., 363 .

${ }^{13}$ Walsh v. Jenvey, 85 Md. 240, 36 Atl. Rep., 817; Farmer v. Francis, I2 Ired. (N. C.), 282; Eaton v. Gladwell, I2I Mich., 444, 80 N. W. 292. On acceptance plaintiff may recover recouping damages.

${ }_{14}$ Dermott v. Jones, 23 How., 220, L. ed.; Sheppard v. Dowling, 103 Ala., 563, I5 So. Rep., 846; Bush v. Finucane, 8 Colo., 192, 6 Pac. Rep., 514; Adlard v. Muldoon, 45 Ill., 193; Estep v. Fenton, 66 Ill., 467 ; Epperly v. Bailey, 3 Ind., 72; Barkalow v. Pfeiffer, 38 Ind., 214; Jewett $v$. Weston, II Me., 346; Bee Printing Co. v. Hichborn, 4 All., 63; Phelps v. Beebe, 7x Mich., 554;Keith v. Ridge, 146 Mo., 90, 47 S. W., g04; Horn v. Batchelder, 4I N. H., 86; Pullman v. Corning, 9 N. Y., 93; Barker v. Troy \& Rutland R. R. Co., 27 Vt., 766.

${ }^{15}$ Garland v. New Orleans, 13 La. Ann., 43. 
out his undertaking, has no equitable claim to any compensation whatever, and in most jurisdictions is allowed to recover. nothing. ${ }^{10}$ In some jurisdictions, however, following the celebrated case of Britton $v$. Turner, ${ }^{17}$ the contractor is allowed to recover some compensation for the work he has done. ${ }^{18}$

${ }^{16} 2$ Sedg. Dam. 8th Ed., Sect. 659. This is the case when there is a voluntary abandonment of the contract without excuse: Hansbrough $v$. Beck, 5 Wall., 497, 18 L. ed., 520; Hazskins v. Gilbert, I9 Ala., 54; Golden Gate Lumber Co. v. Sahrbacher, I05 Cal, II4, 38 Pac., 635; Demead v. Coburn, I5 Md. 29; Homer v. Shaw, I77 Mass., I, 58 N. E. Rep., I60; Jennings v. Camp, 13 Johns. 94, 7 Am. Dec., 367; Brown v. Weber, 38 N. Y., I87; Glacius v. Black, 50 N. Y., I45, ro Am. Rep., 449; Crane v. Kunbel, 6r N. Y., 645; Cunningham v. Jones, 4 Abb. Pr., 433. Or where the work is completed, but fails in some substantial particular to comply with the requirements of the contract: Ellis v. Hamlen, 3 Taunt., 52; Whitaker v. Dunn, 3 T. L. Rep., 602; Elliott v. Caldwell, 43 Minn., 357, 45 N. W. Rep., 845, 9 L. R. A., 52; Bozarth v. Dudley, 44 N. J. L., 304, 43 Am. Rep., 373; Feeney v. Bardsley, 66 N. J. L., 239, 49 Atl. Rep., 443; Smith v. Brady, 17 N. Y., 173, 72 Am. Dec., 442; Glacius $v$ : Black, 50 N. Y., I45, 10 Am. Rep., 449; Mehurin v. Stone, 37 Ohio St., 49; Shires v. O'Connor, $4 \mathrm{~Pa}$. Super. Ct. 465 ; Hulst v. Benevolent Hall Assoc., $9 \mathrm{~S}$. D., 144, 68 N. W. Rep., 200; Sherlock v. Powell, 25 Ont. App., 407. It seems that if the contractor upon abandonment forfeits his right to compensation, this is an end to rights on the contract for either party. The owner cannot sue the contractor for damages for non-performance without making allowance for the work done by the contractor. Griffin v. Miner, 54 N. Y. Super. Ct., 46 .

176 N. H., 48 r.

${ }^{18} 2$ Sedg. Dam., 8th ed., Sect. 660. The cases in which this doctrine is laid down are usually cases where the work was completed, but there were serious defects in it. Heman v. Compton Hill Imp. Co., $58 \mathrm{Mo}$. App., $480 ;$ Muller v. Gillick, 66 Mo. App., 500; Danforth v. Freeman, 69 N. H., 466, 43 Atl., 62I; Cox v. Estell, Peck (Tenn.), I75; Twitty v. McGuire, 3 Murph. (Tenn.), 5or ; Elliott v. Wilkinson, 8 Yerg. (Tenn.), $4 \mathrm{II}$; Porter v. Woods, 3 Humph. (Tenn.) 56, 39 Am. Dec. I53; Gibson v. Carlin, I3 Lea (Tenn.), 440; Deberry v. Young, I Tenn. Cas., 5I; Bush v. Jones, 2 Tenn. Cas., 224; Gonales College v. McHigh, 21 Tex., 256. But in many States, the plaintiff is alowed to recover if his work has been $0 \hat{i}$ actual benefit to the defendant, even though he has intentionally abandoned the work before completion and without excuse. Walworth $v$. Finnegan, 33 Ark., 751; Jewett v. Weston, II Me., 346; Norris v. School Dist., I2 Me., 293, 28 Am. Dec., I82; Porter v. Woods, 3 Humph., 56, 39 Am. Dec., 153; Hillyard v. Crabtree, II Tex., 264, 62 Am. Dec., 475 ; Gonzales College v. McHugh, 21 Tex., 256; Carroll v. Welch, 26 Tex., 147; ITatson v. DeWitt County, 19 Tex. Civ. App., 150, 46 S. W., 106r; $B$. \& $O . R . R$. Co. v. Lafferty, 2 W. Va., ro4. The rule is otherwise in Vermont and Kentucky which, nevertheless, accept the doctrine of Britton $v$. Turner in cases where the abandonment was not wilful. Austin v. Austin, $47 \mathrm{Vt}$., 311; Escott v. White, 10 Bush. (Ky.), I69. 


\section{III.}

\section{Express Contract Rescinded.}

The term "Rescission" should legally be confined to cases where a contract is rightfully put an end to during the performance of it and before the performance is completed. This may be done by mutual consent of the parties or it may under certain circumstances be the act of one party alone. For instance, if one party is induced to enter into a contract by the fraud of the other party to it, he may avoid or rescind the contract. Even if the contract was legally entered into, one party, according to most authorities, may elect to rescind the contract if full performance of it is prevented by the other party. Under some circumstances it has even been held that one party may rescind a contract because of a breach of it by the other party, although it is still entirely possible for the former to continue and complete the performance on his side. In all these cases the rescission is legally accomplished because of a right given by law to the rescinding party.

Rescission, properly so called, is sometimes confounded with the repudiation of the contract by one party. This, however, is an improper ușe of the term.

Whenever a party to the contract is given the right to rescind because of a breach by the other party this is merely an optional right. He may, if he choose, continue to claim his right to the performance of the contract and may bring suit upon the special agreement and recover damages for the breach of it, which will include loss of profit if any can be proved. On the other hand, if he choose, he may rescind the contract and claim the rights which arise from rescission. ${ }^{19}$

If a party to a contract elects to rescind it he cannot then continue to claim the benefits of the contract. He cannot go on and perform it, nor can he claim compensation for loss of profits of it. His election involves an abandonment of any claim whatever to the performance of the contract and he can make no other claim than for a return of the benefit conferred

${ }^{19}$ Wilson v. Bauman, 80 Ill., 493; North v. Mallory, 94 Ind., 305, 51 Atl., 89; Thompson $v$. Gaffey. 52 Neb., 317, 72 N. W., 314; Derby v. Jolnnson, 21 Vt., I7. 
by him. ${ }^{20}$ Consequently, where the non-payment of an installment under a contract is held to justify rescission, a party cannot sue for breach of the contract on such non-payment and recover for loss of profits of the contract. If he chooses to keep the contract alive, he must continue performance; but if he elects to regard the contract as rescinded, he has no claim to the profits. ${ }^{21}$

Upon the recission of a contract both parties to it have the right to be replaced so far as that is possible in the condition in which they were before performance of the contract began. In other words, each side is entitled to a return of anything which it has given to the other on account of the contract or in performance of it. Since one of the parties is in the wrong, the other party must be preferred on both sides of this return; and if a complete return of the benefits on both sides cannot be made without injustice to the wronged party, then the return must be made to the rescinding party and not to the wrong-doing party. In most cases, however, no difficulty will be found in securing a return of benefits.

When the rescinding party to a contract has given property or has performed services either in consideration for the contract or in partial performance of it, he is entitled upon rescission, as has been seen, to a return of the property or the services. In case of property this return can often be made in specie. In case of service there can be no return in specie. Where no return can be made of the exact benefit conferred, the plaintiff is entitled to recover in an action on a quantum meruit or quantum valebat, the value of the services conferred ${ }^{22}$ or the property given ${ }^{23}$ in

20 Therefore, if the plaintiff continues performance after his right to rescind accrues, he cannot afterward change his mind, and claim to recover on a quantum meruit. Meyer v. Hallock, 2 Robert (N. Y.), 284; Shaw v. Turnpike, 3 P. \& W. (Pa.), 445.

${ }_{21}$ Cox v. McLaughlin, 54 Cal., 605; Christian County v. Oveholt, 18 Ill., 223 ; Beatty v. Howe Lumber Co., 77 Minn., 272, 79 N. W. Rep., Ior3; Wharton v. Winch, I40 N. Y., 287, 35 N. E. Rep., 589; Jones v. N. Y., 57 App. Div., 403, 68 N. Y. Supp., 228.

22 Britt v. Hays, 2I Ga., I57; Selby v. Hutchinson, 9 Ill., 3I9; Webster v. Enficld, to I11., 298; Dobbins v. Higgins, 78 Ill., 440; Wilson v. Bauman, 8o Ill., 493; Marquis v. Lauretson, 76 Ia.; 23; Thompson v. Brown, 106 Iowa, 367, 67 N. W. Rep., 819; Black v. Woodrow, 39 Md., r94; Bush v. Brooks, 70 Mich., 446, 38 N. W. Rep., 562; Simmons v. Ocean Causeway, 2I App. Div., 30, 47 N. Y. Supp., 360; Hardiman v. Mayor, 21 App. Div., 6I4, 47 N. Y. Supp., 786; Green v. Haley, R. I., 260; Preble v. Bottom, 27 Vt., 249; Fitch v. Casey, 2 G. Greene (Ia.), 300.

23 Bennett v. Phelps, 12 Minn., 326. 
lieu of a return in specie; and since this is not a suit on the contract, but merely a recovery of the benefit conferred by performance for the purpose of replacing the parties in their original position, the contract price is immaterial, 24 and so is the value of the services to the defendant. ${ }^{25}$ But the cost to the plaintiff may be shown as evidence of the value. ${ }^{28}$ In a few States, however, the courts, overlooking the consideration that this is not a suit for breach of contract, but to recover for goods delivered or services rendered, on a consideration failed, hold that the recovery must be at the contract rate, ${ }^{27}$ or at least cannot exceed the contract price, ${ }^{28}$ unless the circumstances are such as to show that the expense of the part performance was greater than the average expense of full performance. ${ }^{20}$ This amounts to giving the defendant the benefit of the contract which by his default it is agreed that the plaintiff has a right to destroy. Where the contract is divisible, so that a contract price is named for each of several acts of performance, and some of the acts have been completed before rescission, the contract price alone is recoverable for these acts; the value of the performance cannot be demanded. ${ }^{30}$

When the contract contains a clause permitting one party to cancel it upon notice to the other, and the contract is so cancelled after part performance, the party who has partly performed

24 Fitch v. Casey, 2 G. Greene (Ia.), 300; Rodemer v. Hazelhurst, 9 Gill, 288; North v. Mallory, 94 Md., 305. 51 Atl., 89; Connolly v.,Sullivan, 53 N. E. I43; Henminger v. Western Assur. Co., 95 Mich., 355.54 N. W. Rep. 949; Thompson v. Gaffey, 52 Neb., 317, 72 N. W. Rep., 314; Merrill v. Ithaca \& O. R. R. Co., I6 Wend. (N. Y.), 586; (Cf. Koon v. Greenman, 7 Wend. (N. Y.), I2I) ; Derby v. Johnson, 2I Vt., I7.

${ }^{25}$ San Francisco Bridge Co. v. Dumbarton Land \& Imp. Co., IIg Cal., 272, 5 I Pac., 335.

${ }^{20}$ Simmons v. Ocean Causezuay, 21 App. Div., 30, 47 N. Y. Supp., 360.

${ }^{27}$ Reynolds v. Jourdan, 6 Cal., I08; Wiegel v. Boone, 64 Ark., 228, $4 \mathrm{I}$ S. W. Rep., 763; Chicago Training School v. Davies, 64 Ill. App., 503; Rice v. Partello, 88 Ill. App., 52; Hoyle v. Stellwagen, 28 Ind. App., 68I, 63 N. E. Rep., 780; Kehoe v. Rutherford, 56 N. J. L., 23, 27 Atl. Rep., 912.

${ }^{28}$ Folliott v. Hunt, 2r Ill., 654; Steinburg v. Gebhadt, 4I Mo., 519.

20 Wellston Coal Co. v. Franklin Paper Co., 57 Ohio St., 182, 48 N. E., 888 (agreement to buy coal for a year at a certain rate; after coal had been received during the period of highest price, buyer repudiated; seller may recover for portion delivered at market rate).

${ }^{30}$ Marquis v. Lauretson, 75 Ia., 23; Rodemer v. Hazelhurst, 9 Gill (Md.), 288. See Wiegel v. Boone, 64 Ark., 228, 41 S. W., 763. 
may recover compensation for the work he has done at the contract rate. ${ }^{81}$

When a contract is rescinded after part performance by the mutual consent of the parties, a party who has partially performed the contract may in the ordinary case recover the value of such performance according to the contract price; the amount recoverable depending upon the ratio of the value of the labor and materials actually furnished to the total value of all the labor and materials which would have been required for the performance of the contract. ${ }^{32}$ If, however, the circumstances of the rescission are such as to make it clear that neither party was to have compensation, this will not be allowed. So when the plaintiff, who had contracted to build a mill, built it so badly that it was entirely useless, and by agreement of the parties the mill was entirely-rebuilt, the builder was allowed to recover nothing for the first building, but was restricted to compensation for the rebuilding. ${ }^{83}$

Rescission of a contract may take place by an act of the law or by inevitable accident. In that case, also, recovery may be had for the work done before the rescission.

Where by a change of law during the progress of the work the completion of a contract made is impossible, the contractor may recover at the contract rate for the work already done. ${ }^{34}$ And so when the full performance of work is prevented by an injunction. recovery may be had for the part performed before the injunc-

31 Chicago v. Sexton, Ir5 IIl., 230, 2 N. E., 263; Fitzgerald v. Allen, 128 Mass., 232; Dolan v. Rodgers, 149 N. Y., 489, 44 N. E. Rep., 167. In Lyman v. Lincoln, $38 \mathrm{Neb}$., 794, 57 N. W., 53I, however, where the city cancelled a contract to build an engine house under a power reserved to it in the contract, it was held that it could not thereafter use the contract price for the purpose of diminishing plaintiff's claim. Plaintiff is entitled to recover the amount of actual benefit which the city received independently of the terms of the contract.

32 Charleston Ice Manuf. Co. v. Joyce, 63 Fed. Rep., 916, II C. C. A., 496; Schillo v. McEwen, 90 Ill., 77; McAfferty v. Hale, 24 Ia., 355; Connolly v. Sullivan, 53 N. E., I43; Delaware \& H. Canal Co. v. Dubois, I5 Wend., 87, affirming Dubois v. C. Co., I2 Wend., 334; Farmer v. Francis, I2 Ire. (N. C.), 282.

s3 Simpson v. McDonald, 2 Ark., 370.

s4 Jones v. Judd, 4 N. Y., $41 \mathrm{I}$; Heine v. Meyer, 6I N. Y., I7I, 20 Am. Rep., 475 . 
tion was issued at the contract rate, or at least according to the value of the services rendered..$^{35}$

When one undertakes to do work upon the property of another, and before the completion of the work the property is destroyed by act of God, the contractor is entitled to recover compensation for the work he has done. ${ }^{30}$ So where a contractor undertakes to do work on the defendant's building, and the building is blown down before completion of the work, the contractor may recover compensation for his work, ${ }^{37}$ and if both sides of the contract have been partly executed before the destruction, compensation may be recovered on both sides for what has been done. ${ }^{38}$ So where one is to make repairs on the house of another under a special contract, or is to furnish a part of the work and materials used in the erection of a house, and his contract becomes impossible of performance on account of the destruction of the house by fire, he may recover for what he has done or finished. ${ }^{30}$ And on the same principle recovery may be had for labor and materials where the plaintiff had undertaken to install a heating

${ }^{35}$ Whitfield v. Zellnor, 24 Miss., 663; Theobald v. Burleigh, 66 N. H., 574, 23 Atl. Rep., 367; Doolittle v. Nash, 48 Vt., 441.

${ }^{38}$ See on this doctrine the cases subsequently cited in notes 7 to 14 . The opposite doctrine prevails in England. Appleby v. Myers, L. R. 2 C. P., 651 (contract to put machinery into defendant's building). And see Brumby v. Smith, 3 Ala., I23; Shanks $v$. Griffin, 14 B. Mon., I53. If it is still possible to restore and complete the work the plaintiff must do so before he will be entitled to recover compensation; as where he undertakes to erect a building on land, and it is blown or burned down before completion. The plaintiff is not thereby discharged from his obligation to perform. Schwartz v. Saunders, 46 Ill., I8; Adams v. Nichols, I9 Pick., 275, 3I Am. Dec., 137; Tompkins v. Dudley, 25 N. Y., 272, 82 Am. Dec., 349; Galyon v. Ketchen, 85 Tenn., 55, I S. W., 508; Weis v. Devlin, 67 Tex., 507, 3 S. W., 726, 60 Am. Rep., 38; School Trustees v. Bennett, 27 N. J. L., 5I3, 72 Am. Dec., 373.

${ }^{37}$ Schwartz v. Saunders, 46 Ill., I8; Garretty v. Brazell, 34 Iowa, 1oo.

${ }^{38}$ Butterfield v. Byron, 153 Mass., 517, 27 N. E., 667, 25 Am. St. Rep, 654 , I2 L. R. A., 57 I.

${ }^{39}$ Rawson v. Clark, 70 Ill., 656; Cleery v. Schicr, 120 Mass., 210; Butterfield v. Byron, 153 Mass.; 517, 27 N. E. Rep., 667, 25 Am. St., 654, I2 L. R. A., 571 ; Niblo v. Binsse, I Keyes, 476; Hayes v. Gross, 9 App. Div., 12, 40 N. Y. Supp., 1098; Hollis v. Chapman, 36 Tex., I; Weis v. Devlin, 67 Tex., 507, 3 S. W. Rep., 726, 60 Am. Rep., 38; Hysell v. Sterling Coal fo Manuf. Co., 46 W. Va., 158, 33 S. E. Rep., 95; Cook v. McCabe, 53 Wis., 250, 40 Am. Rep., 765, Io N. W. Rep., 507. 
or lighting plant in a building, ${ }^{40}$ to move a building, ${ }^{41}$ to build a house from the defendant's materials, ${ }^{42}$ to make gloves from the defendant's materials, ${ }^{43}$ or to repair the defendant's vessel, ${ }^{44}$ and the building, the materials, or the vessel, are destroyed by fire before complete performance.

According to the weight of authority, this recovery is to be had at the contract rate, so far as this can be applied to the case. ${ }^{45}$ In some States, however, the reasonable value of the work and materials is to be recovered and not the pro rata portion of the contract price. ${ }^{46}$ Since neither party is in fault, neither has forfeited the right to rely on the contract; and the better view, therefore, is to allow recovery at the contract rate.

\section{IV.}

\section{No Express Contract.}

Where work is done at request or without any express agreement for payment, there is nevertheless understood by the parties, though not expressed in words, an agreement to pay for the work done. In that case the amount of recovery is the actual value of the services rendered, not of the product of the services. ${ }^{47}$ Or if it was a contract for the use of property, the amount of recovery is the value of the use. ${ }^{48}$ If the contractor hired workmen

${ }^{40}$ Kenzwood Bridge Co. v. Dunderdale, 50 Ill. App., 581 ; Niblo v. Binsse, I Keyes, 476 .

41 Angus v. Scully, I76 Mass., 357, 57 N. E. Rep., 674, 49 L. R. A., 562.

42 Wilson v. Knott, 3 Humph., 473, 39 Am. Dec., I65.

${ }_{43}$ Labowitz v. Frankfort, 4 N. Y. Misc., 275, 23 N. Y. Supp., to38.

44 Menetone v. Athawes, 3 Burr 1592.

${ }_{45}$ Schwartz v. Saunders, 46 Ill., I8; Rawson v. Clark, 70 Ill., 656; Clark v. Busse, 82 Ill., 515; Butterfield v. Byron, 153 Mass., 517, 27 N. E. 667, 25 Am. St. Rep., 654, 12 L. R. A., 57I; Niblo v. Binsse, I Keyes, 476; Hayes v. Gross, 9 App. Div., 12, 40 N. Y. Supp., 1098; Labowitz v. Frankfort, 4 N. Y. Misc., 275, 23 N. Y. Supp., ro38; Hollis v. Chapman, 36 Tex., I Clark v. Franklin, 7 Leigh (Va.), I; Cook v. McCabe, 53 Wis., 250, 10 N. W., 507, 40 Am. Rep., 765 .

40 Wilson v. Knott, 3 Humph. (Tenn.), 473, 39 Am. Dec., I65.

${ }_{4}$ Charleston I. M. Co. v. Joyce, 63 Fed., 916, II C. C. A., 496 (boring well) ; Ennis v. Pullman P. C. Co., Ill. 46 N. E., 439 (professional services); Snow v. Ware, I3 Met. (Mass.), 42 (building road); Turncr $v$. Mason, 65 Mich., 662,32 N. W., 846 (painting portrait). It is the net value, deducting an allowance for defective workmanship. Wright $z$ : Calmpsty, 4I $\mathrm{Pa}$., 102.

18 Adamson v. Adamson, 9 Ark., 25 (slaves). 
to do the work, the amount recoverable is not what he paid his own workmen, but the value of their services. ${ }^{49}$

Where extra work is done outside an express contract, by consent or at the request of the other party to the contract, the party doing the work is entitled to recover the value of it. This will be paid for in the ordinary case at a rate no greater than the contract rate, if that can be traced.50 If, however, circumstances make the extra work more costly than it was at the time the contract was entered into, the contract price ceases to be a guide in estimating the compensation for the extra work. ${ }^{61}$

If the extra work is so different from the work provided for in the contract that the prices named in the contract furnish no proper guide to the value of the extra work, or if the nature of the contract is so modified by the changes that the original prices cannot be traced in the new work, the plaintiff may recover the value of the work. ${ }^{22}$ Where, however, the recovery is based not upon a real, though unexpressed contract, but upon an unjust enrichment of the defendant; that is, where the cause of action is in quasi-contract, the amount of recovery should strictly be limited to the unjust enrichment conferred upon the defendant by the plaintiff's labor. In many such cases the benefit conferred on the defendant is the same as the value of the services of the plaintiff. Thus where the plaintiff is entitled to recover money paid under a mistake, or otherwise under circumstances giving him a claim to get it back, the measure of recovery is the money thus paid, with legal interest.ss And where the plaintiff is en-

\footnotetext{
10 Hauptman v. Catlin, I E. D. Smith (N. Y.), 729.

so Jones v. Woodbury, in B. Mon. (Ky.), I67.

${ }^{61}$ Harrison Co. v. Byrne, 67 Ind., 21; Slusser v. Burlington, 47 Iowa, 300 (hard pan); Turner v. Grand Rapids, 20 Mich., 390 (bad state of weather); Dubois v. Delaware \& H. C. Co., I2 Wend. (N. Y.), 334, 15 Wend., 87 (hard pan).

${ }^{52}$ Charleston Ice Manuf. Co. v. Joyce, 63 Fed., 916, II C. C. A., 496; Chicago R. R. v. Vosburgh, 46 IIl., 311; Western Union R. Co. v. Smith, 75 Ill., 496; Elgin v. Joslyn, I36 Ill., 525, 26 N. E. Rep., 1090; Street v. Swain, 2I Ind., 203; Bailey v. Woods, 17 N. W. 365; Wheeden v. Fiske. 50 N. H., I25; Hollinshead v. Mactier, 13 Wend. (N. Y.), 276; Rhodes v. Clute, I7 Utah, 137, 53 Pac., 990 ; Hood v. Smiley, 5 Wyo., 70, 96 Pac., 856.

${ }^{53}$ Deery $v$. Hamilton, $4 \mathrm{I}$ Ia., I6. If part of the amount paid really belonged to the defendant, the plaintiff can recover the balance. Merchants' Bank v. Bank of Commonwealth, I39 Mass., 513 (overpayment of check); Western Assur. Co. v. Towle, 65 Wis. 2.47 (overpayment of insurance loss, owing to fraud of assured).
} 
titled to recover money reasonably paid out for the funeral expenses of a person whom defendant was bound to bury, the amount of money paid is the measure of recovery, as it is also the measure of the enrichment. ${ }^{\overline{4}}$ So where plaintiff rendered services in saving defendant's property from destruction, the defendant's enrichment was the value of the services, and that is the amount of recovery. ${ }^{55}$ In a few cases, however, the amount of the enrichment and the value of the services are not the same; and in such cases the plaintiff's recovery is restricted to the amount of the enrichment. So where a purchaser of land under a parol contract entered into possession and made improvements on the land, upon being ejected by the owner, who took advantage of the Statute of Frauds and repudiated the contract, he was entitled to recover the value of the improvements to the owner, not the expense of the improvements. ${ }^{56}$

Joseph H. Beale.

Harvard.Law School.

os Bradshaw v. Beard, 12 C. B., N. S., 344; Cunningham v. Reardon, 98 Mass., 538; Patterson v. Patterson, 59 N. Y., 574.

55 Chase v. Carcoran, 106 Mass., 286; Sheldon v. Sherman, 42 Barb. (N. Y.), 368.

${ }_{5}$ Mathews v. Davis, 6 Humph. (Tenn.), 324. But see Wright $v$. Hasrell, 45 Me., 489; Welch v. Lawson, 32 Miss., I70; Ham v. Goodrich, 37 N. H., I85; Bender v. Bender, 37 Pa., 419. 